\title{
PENTINGNYA PENDIDIKAN GURU YANG PROFESIONAL
}

\author{
Muhammad Heldi \\ Email:2010111210004@ulm.ac.id \\ Program Studi Pendidikan Sejarah Fakultas Keguruan dan IImu Pendidikan \\ Universitas Lambung Mangkurat \\ Banjarmasin
}

\begin{abstract}
Abstrak
Melatih kepribadian guru merupakan salah satu hal yang tetap harus dikembangkan dan berkelanjutan. Pembinaan dan pengembangan profesi guru meliputi pembinaan kompetensi pedagogis, kepribadian, profesional dan sosial. Pelatihan dan pengembangan profesi guru dimaksud antara lain dilakukan melalui pendidikan dan pelatihan dalam jabatan. Berkaitan dengan tanggung jawab sebagai seorang guru tanggung jawab adalah hal yang sangat penting karena guru adalah seorang individu yang berkecimpung dalam dunia pendidikan yang harus melaksanakan tanggung jawabnya sebagai pendidik bagi peserta didik pada saat di lingkungan sekolah. Guru sebagai pendidik juga harus bertanggung jawab atas segala tindakan dan perbuatannya pada saat pembelajaran disekolah maupun di dalam kehidupan bermasyarakat. Berkenaan wibawa, seorang guru dalam dirinya harus memiliki kepribadian yang mampu merealisasikan nilai spiritual, moral emosional, sosial, dan intelektual. Guru juga harus memiliki kelebihan dalam bidang ilmu pengetahuan dan teknologi hal ini bertujuan agar seorang guru dapat memberikan pemahaman terhadap peserta didik dalam kegiatan mengajar di sekolah maupun lingkungannya.
\end{abstract}

\section{PENDAHULUAN}

Profesi secara etimologi berasal dari kata profession (inggris) yang berasal dari bahasa Latin profesus yang berarti "mampu atau ahli dalam suatu bentuk pekerjaan". Profesi dapat diartikan sebagai suatu pekerjaan atau jabatan yang menuntut keahlian, yang didapat melalui pendidikan dan latihan tertentu, menurut persyaratan khusus memiliki tanggung jawab dan kode etik tertentu. Pekerjaan yang bersifar profesional berbeda dengan pekerjaan lainnya karena suatu profesi memerlukan kemampuan dan keahlian khusus dalam melaksanakan profesinya. 
Profesi juga diartikan sebagai suatu jabatan atau pekerjaan tertentu yang mensyaratkan pengetahuan dan keterampilan khusus yang diperoleh dari pendidikan akademis yang intensif. Jadi profesi adalah suatu pekerjaan atau jabatan yang menuntut keahlian tertentu. Artinya suatu pekerjaan atau jabatan yang disebut profesi tidak dapat dipegang oleh sembarang orang, tetapi memerlukan persiapan melalui pendidikan dan pelatihan secara khusus (Musriadi 2016: 27-30).

Berdasarkan pada beberapa kriteria tersebut, maka profesi merupakan bidang pekerjaan tertentu yang dinilai telah memenuhi kriteria. Dengan kata lain tidak semua pekerjaan dapat disebut profesi karena terdapat persyaratan persyaratan khusus yang harus dipenuhi sehingga suatu bidang pekerjaan dapat disebut sebagai profesi.

Profesi pada hakikatnya adalah suatu pernyatan atau suatu janji terbuka yang menyatakan bahwa seseorang itu mengabdikan dirinya pada suatu jabatan atau pelayanan karena orang tersebut merasa terpanggil untuk menjabat pekerjaan itu. Istilah profesi merupakan simbol dari suatu pekerjaan itu sendiri, profesi mengajar adalah suatu jabatan yang mempunyai kekhususan. Kekhususan itu merupakan kelengkapan mengajar atau keterampilan yang menggambarkan bahwa seseorang melakukan tugas mengajar, yaitu membimbing manusia (Musriadi, 2016: 30).

Berdasarkan pengertian di atas, meskipun profesi adalah karir seumur hidup dan ada konsekuensi ekonomis atas pekerjaan di bidang profesi tersebut akan tetapi fokus utamya terletak pada pengabdian dan tanggungjawab moril sesuai bidang keilmuan profesi. Dengan demikian tanggungjawab insan profesi bukan hanya kepada atasan atau pemerintah, melainkan juga kepada bidang keilmuan dan kemanusiaan. Tanggung jawab tersebut juga menjadi pembeda antara profesi dengan bidang pekerjaan lain yang bukan profesi.

Secara umum syarat suatu pekerjaan untuk dapat digolongkan menjadi suatu profesi yaitu:

1) Memiliki spesialisasi ilmu; setiap profesi dibangun berdasarkan kekhususan keilmuan, sehingga orang yang masuk dalam suatu bidang profesi haruslah orang yang memiliki latar belakang keilmuan yang sesuai. Hal ini menjelaskan bahwa tidak sembarang orang dapat bekerja di suatu bidang profesi jika tidak memiliki latar belakang keilmuan yang relevan.

2) Memiliki kode etik dalam menjalankan profesi; kode etik merupakan pedoman etik/pedoman moral bagi anggota profesi dalam menjalankan tugasnya. Kode etik profesi diperlukan untuk menjaga martabat dan menjadi pedoman bagi insan 
profesi dalam menjalankan profesinya.

3) Memiliki organisasi profesi; organisasi merupakan wadah perjuangan dan perkumpulan insan profesi. Organisasi profesi juga berfungsi sebagai wadah untuk pengembangan profesi melalui sharing inovasi dan komunikasi suatu profesi. Melalui organisasi ini insan profesi akan memiliki kesepakatan yang sama dalam menjalankan profesinya dan memiliki kemampuan untuk merespon berbagai kebijakan dan tantangan terkait profesi. Organisasi profesi dapat menjadi simbol kuatnya suatu profesi di tengah masyarakat.

4) Diakui masyarakat; suatu profesi harus mendapat pengakuan masyarakat. Pengakuan ini diperoleh jika profesi tersebut telah terbukti memiliki peran sesuai bidangnya. Pengakuan masyarakat merupakan bentuk legimitasi terhadap keberadaan dan peran suatu profesi.

5) Sebagai panggilan hidup; profesi merupakan karir sepanjang hayat, dengan demikian profesi akan mendarah daging bagi orang yang menjalankannya. Bekerja di bidang profesi sangat berbeda dengan bekerja di bidang lain bekerja di bidang profesi mengharuskan seseorang untuk mengabdikan diri secara penuh dan terus mendalami keilmuan bidang profesi tersebut sehingga semakin lama seseorang berkecimpung dalam suatu bidang profesi maka akan semakin ahli dalam bidang tersebut.

6) Dilengkapi kecakapan diagnostik; sebagai bidang pekerjaan yang memerlukan pengambilan keputusan otonom dari insan profesi, maka orang yang bekerja di bidang profesi diharuskan memiliki kemampuan diagnostik. Kemampuan diagnostik adalah kemampuan memperkirakan penyebab dan atau akibat berdasarkan gejala atau ciri-ciri tertentu, menganalisis, serta kemampuan untuk menentukan tindakan yang tepat untuk menangani atau menyelesaikan permasalahan.

7) Mempunyai klien yang jelas; karena profesi merupakan pekerjaan di bidang jasa, maka setiap profesi pasti memiliki klien yang jelas. Dokter memiliki klien pasien, pengacara memiliki klien orang yang berperkara hukum, guru memiliki klien murid. Kejelasan klien ini yang menunjukkan bahwa bidang profesi adalah pekerjaan yang sangat spesifik dan berbeda antara satu profesi dengan profesi lainnya, sehingga seseorang tidak dapat beralih profesi tanpa latar belakang pendidikan dan keahlian yang relevan. 


\section{Profesi guru}

Bedasarkan UU RI No.14 tahun 2005 tentang Guru dan Dosen Pasal 1Guru adalah pendidik profesional dengan tugas utama mendidik, mengajar membimbing, mengarahkan, melatih, menilai, dan mengevaluasi peserta didik pada pendidikan anak usia dini jalur pendidikan formal, pendidikan dasar, dan pendidikan menengah. Dosen adalah pendidik profesional dan ilmuan dengan tugas utama mentransformasikan, mengembangkan, dan menyebarluaskan ilmu pengetahuan, teknologi, dan seni melalui pendidikan, penelitian, dan pengabdian kepada masyarakat.

Menurut Noor Jamaluddin (1978: 1) Guru adalah pendidik, yaitu orang dewasa yang bertanggung jawab memberi bimbingan atau bantuan kepada anak didik dalam perkembangan jasmani dan rohaninya agar mencapai kedewasaannya, mampu berdiri sendiri dapat melaksanakan tugasnya sebagai makhluk Allah khalifah di muka bumi, sebagai makhluk sosial dan individu yang sanggup berdiri sendiri. Sedangkan Rickey (1987) sebagaimana dikutif Soetjipto dan Kosasi (2009: 17) mengemukakan ciri-ciri guru sebagai profesi, yaitu:

1) Adanya komitmen dari para guru bahwa jabatan itu mengharuskan pengikutnya menjunjung tinggi martabat kemanusiaan lebih dari pada mencari keuntungan diri sendiri.

2) Suatu profesi mensyaratkan orangnya mengikuti persiapan profesional dalam jangka waktu tertentu.

3) Harus selalu menambah pengetahuan agar terus menerus berkembang dalam jabatannya.

4) Memiliki kode etik jabatan.

5) Memiliki kemampuan intelektual menjawab masalah-masalah yang dihadapi.

6) Selalu ingin belajar terus-menerus mengenai bidang keahlian yang ditekuni.

7) Menjadi anggota dari suatu organisasi profesi.

8) Jabatan itu dipandang sebagai suatu karir hidup.

Guru merupakan suatu profesi, yang berarti suatu jabatan yang memerlukan keahlian khusus sebagai guru dan tidak dapat dilakukan oleh sembarang orang diluar bidang pendidikan. Walaupun pada kenyataannya masih terdapat guru yang tidak memiliki latar belakang pendidikan bidang keguruan. Seorang guru berkaitan dengan aktivitas profesinya duharuskan mengetahui dan dapat menerapkan beberapa prinsip mengajar agar ia dapat melaksanakan 
tugasnya secara profesional, yaitu sebagai berikut.

1) Guru harus dapat membangkitkan perhatian perserta didik pada materi pelajaran yang diberikan serta dapat menggunakan berbagai media dan sumber belajar yang bervariasi.

2) Guru harus dapat membangkitkan minat peserta didik untuk aktif dalam bepikir serta mencari dan menemukan sendiri pengetahuan.

3) Guru harus dapat membuat urutan (sequence) dalam pemberian pelajaran dan penyesuaiannya dengan usia dan tahap tugas perkembangan peseta didik.

4) Guru perlu menghubungkan pelajaran yang akan diberikan dengan pengetahuan yang telah dimiliki peserta didik (kegiatan apersepsi), agar peserta didik menjadi mudah dalam memahami pelajaran yang diterimanya.

5) Sesuai dengan prinsip repetisi dalam proses pembelajaran, diharapkan guru dapat menjelaskan unit pelajaran secara berulang-ulang hingga tanggapan peserta didik menjadi jelas.

6) Guru wajib memperhatikan dan memikirkan korelasi atau hubungan antara mata pelajaran dan/atau praktik nyata dalam kehidupan sehari-hari.

7) Guru harus tetap menjaga konsentrasi belajar para peserta didik dengan cara memberikan kesempatan berupa pengalaman secara langsung, mengamati/meneliti, dan menyimpulkan pengetahuan yang didapatkanya.

8) Guru harus mengembangkan sikap peserta didik dalam membina hubungan sosial,baik dalam kelas maupun diluar kelas.

9) Guru harus menyelidiki dan mendalami perbedaan peserta secara individual agar dapat melayani siswa sesuai dengan perbedaannya tersebut. 


\section{PERAN GURU SEBAGAI SEBUAH PROFESI}

Guru merupakan suatu profesi, yang berarti suatu jabatan yang memerlukan keahlian khusus sebagai guru dan tidak dapat dilakukan oleh sembarang orang diluar bidang pendidikan. Walaupun pada kenyataannya masih terdapat guru yang tidak memiliki latar belakang pendidikan bidang keguruan.

Guru dapat melaksanakan evaluasi yang efektif serta menggunakan hasilnya untuk mengetahui peserta dan kemajuan siswa serta dapat melakukan perbaikan dan pengembangan.

Seiring dengan kemajuan teknologi informasi yang telah demikian pesat, guru tidak lagi hanya bertindak sebagai penyaji informasi, tetapi juga harus mampu bertindak sebagai fasilitator, motivator, dan pembimbingan yang lebih banyak memberikan kesempatan kepada peserta didik untuk mencari dan mengolah sendiri informasi. Dengan demikian, keahlian guru harus terus dikembangkan dan tidak hanya terbatas pada penguasaan prinsip mengajar seperti telah diuraikan.

Guru merupakan profesi tertua didunia seumur dengan keberadaan manusia. Bukankah ibu dan keluarga merupakan guru yang pertama dalam kehidupan. Tidak mengherankan apabila di dalam masyarakat, profesi guru dianggap dapat dilakukan oleh semua orang. Sehingga sekarang ini, pertanyaan yang masih muncul berkaitan dengan profesi guru yaitu "Apakah pekerjaan guru itu suatu profesi?" Pertanyaan ini muncul karena disatu sisi guru adalah pendidik, sehingga banyak yang beranggapan setiap orang dapat dan berhak mendidik (Nurhadi, 2002: 10). Disisi lain ada sebagian orang yang menjadi guru tanpa melalui jalur pendidikan guru tetapi dapat melaksanakan tugasnya sama atau lebih baik dari pada mereka yang berlatar belakang guru.

Guru adalah posisi yang strategis bagi pemberdayaan dan pembelajaran suatu bangsa yang tidak mungkin digantikan oleh unsur manapun dalam kehidupan sebuah bangsa sejak dahulu. Semakin signifikannya keberadaan guru melaksanakan peran dan tugasnya semakin terjamin terciptanya kehandalan dan terbinanya kesiapan seseorang. Dengan kata lain potret manusia yang akan datang tercermin dari potret guru di masa sekarang dan gerak maju dinamika kehidupan sangat bergantung dari "citra" guru di tengah-tengah masyarakat.

Penilaian terhadap profesi guru juga sangat dipengaruhi oleh kebijakan pemerintah suatu negara. Beberapa negara seperti Jepang dan Korena sangat menjunjung profesi guru, sehingga mereka yang ingin masuk ke profesi tersebut harus melalui pendidikan formal sesuai bidang profesi dengan persyaratan yang berat. Di Korea Selatan misalnya untuk bisa masuk sekolah keguruan harus melewati seleksi yang ketat dan standar yang tinggi. Sedangkan di Jepang, guru PNS pernah menjadi golongan PNS yang mendapat gaji palig tinggi. Berbagai perlakuan dan kebijakan di kedua negara tersebut menempatkan profesi guru 
menjadi sejajar dengan profesi lainnya. Di Indonesia penghargaan terhadap profesi guru belumlah sebaik kedua negara tersebut, akan tetapi sejak diterapkannya kebijakan sertifikasi guru profesi guru mengalami kemajuan signifikan. Meskipun demikian, berdasarkan banyak studi menunjukkan belum ada korelasi langsung program sertifikasi guru (terutama jalur PLPG) dengan peningkatan kualitas pendidikan.

Dalam menjalankan tugas dan profesinya, guru memiliki hak dan kewajiban yang harus dilaksanakan dan diperhatikan. Hak guru berarti suatu yang harus didapatkan olehnya setelah ia melaksanakan sejumlah kewajibannya sebagai guru. Kewajiban guru adalah sesuatu yang harus patut dilaksanakan oleh guru dalam menjalankan profesinya. Hak dan kewajiban guru sebagai pendidik diatur di semua peraturan perundang-undangan yang berkaitan dengan pendidikan. Dalam UU No. 14 Tahun 2005 tentang guru dan dosen pada bagian kedua mengenai hak dan kewajiban pada pasal 14, adapun hak yang dimiliki oleh seorang guru sebagai berikut:

a.) Memperoleh penghasilan di atas kebutuhan hidup minimum dan jaminan kesejahteraan sosial.

b.) Mendapatkan promosi dan penghargaan sesuai dengan tugas dan prestasi kerja.

c.) Memperoleh perlindungan dalam melaksanakan tugas dan hak atas kekayaan intelektual.

d.) Memperoleh kesempatan untuk meningkatkan kompetensi.

e.) Memperoleh dan memanfaatkan sarana dan prasarana pembelajaran untuk menunjang kelancaran tugas keprofesionalan.

f.) Memiliki kebebasan dalam memberikan penilaian dan ikut menentukan kelulusan, penghargaan, dan atau sanksi kepada peserta didik sesuai dengan kaidah pendidikan, kode etik guru, dan peraturan perundang-undangan.

g.) Memperoleh rasa aman dan jaminan keselamatan dalam melaksanakan tugas.

h.) Memiliki kebebasan untuk berserikat dalam organisasi profesi.

i.) Memiliki kesempatan untuk berperan dalam penentuan kebijakan pendidikan.

j.) Memperoleh kesempatan untuk mengembangkan dan meningkatkan kualifikasi akademik dan kompetensi.

k.) Memperoleh pelatihan dan pengembangan profesi dalam bidangnya.

Bila dipahami, maka tugas guru tidak hanya sebatas dinding sekolah, tetapi juga sebagai penghubung antara sekolah dan masyarakat. Bahkan bila dirinci lebih 
jauh, tugas guru tidak hanya yang telah di sebutkan. Menurut Roestiyah N.K., (1989) bahwa guru dalam mendidik anak didik bertugas untuk :

a. Menyerahkan kebudayaan kepada anak didik berupa kepandaian, kecakapan, dan pengalaman-pengalaman.

b. Membentuk kepribadian anak yang harmonis, sesuai cita-cita dan dasar negara kita pancasila.

c. Menyiapkan anak menjadi warga negara yang baik sesuai undang-undang pendidikan.

d. Sebagai perantara dalam belajar. Didalam proses belajar guru hanya sebagai perantara/medium, anak harus berusaha sendiri mendapatkan suatu pengertian, sehingga timbul perubahan dalam pengetahuan, tinggkah laku, dan sikap.

e. Guru adalah sebagai pembimbing, untuk membawa anak didik ke arah kedewasaan, tidak dapat membentuk anak menurut sekehendaknya.

f. Guru sebagai penghubung antar sekolah dan masyarakat. Anak nantinya akan hidup dan bekerja, serta mengabdikan diri dalam masyarakat, dengan demikian anak harus dilatih dan dibiasakan disekolah dibwah pengawasan guru.

g. Sebagai penegak disiplin, guru menjadi contoh dalam segala hal, tata tertib dapat berjalan bila guru dapat menjalani terlebih dahulu.

h. Guru sebagai administrator dan manajer. Disamping mendidik, seorang guru harus dapat mengerjakan urusan tata usaha seperti membuat buku kas, daftar induk, rapor, daftar gaji dan sebagainya, serta dapat mengkoordinasi segal pekerjaan di sekolah secara demokratis, sehingga suasana pekerjaan penuh dengan rasa kekeluargaaan.

i. Pekerjaan guru sebagai suatu profesi.

j. Guru sebagai perencana kurikulum. Guru menghadapin anak-anak setiap hari, gurulah yang paling tau kebutuhan anak-anak dan masyarakat sekitar, maka dalam penyusunan kurikulum, kebutuhan ini tidak boleh di tinggalkan.

k. Guru sebagai pemimpin (guidance worker). Guru mempunyai kesepatan dan tanggung jawab dalam banyak situasi untuk membimbing anak kearah pemecah soal, membentuk keputusan, dan menghadapkan anak-anak pada problem.

I. Guru sebagai seponsor dalam kegiatan anak-anak. Guru harus turut aktif dalam segala aktivitas anak, misalnya ekstrakurikuler membentuk kelompok belajar dan sebagainya.

Karena profesinya sebagai guru adalah berdasarkan panggilan jiwa, maka bila guru melihat anak didiknya sering berkelahi, meminum-minuman keras, menghisap ganja, datang ke rumah-ru bordil, dan sebagainya, guru merasa sakit hati. Siang atau malam selalu memikirkan bagaimana caranya agar anak didiknya 
dapat dicegah dari perbuatan yang kurang baik, asusila, dan amoral ( Djamarah, 2014: 28-29). Sesunggunya guru yang bertanggung jawab memiliki beberapa sifat, menurut Wens Tanlain dan kawan-kawan (1989:31) yaitu

a. Menerima dan mematuhin norma nilai-nilai kemanusiaan;

b. Memikul tugas mendidik dengan bebas, berani, gembira (tugas bukan menjadi beban baginya);

c. Sadar akan nilai-nilai yang berkaitan dengan perbuatannya serta akibat-akibat yang timbul (kata hati);

d. Menghargai orang lain, termaksud anak didik;

e. Bijaksana dan hati-hati (tidak nekat, tidak semberono, tidak singkat akal);

f. Takwa terhadap tuhan yang maha esa.

\section{GURU INDONESIA DAN TANTANGAN PROFESIONALISME}

Profesional dalam banyak literatur diartikan juga sebagai perilaku kerja yang mengutamakan kesempurnaan hasil dengan menjalankan mekanisme kerja yang benar, berorientasi pada klien, dan menunjukkan sikap tanggung jawab pada pekerjaan. Selanjutnya sikap profesional tersebut dalam praksisnya sering disebut profesionalisme.

Secara leksikal, kata profesional mengarah pada profesionalisme. Dalam kamus besar bahasa Indonesia, profesionalisme mempunyai makna; mutu, kualitas, dan tindak tanduk yang merupakan ciri suatu profesi atau yang profesional. Profesionalisme merupakan sikap dari seorang profesional. Artinya sebuah term yang menjelaskan bahwa setiap pekerjaan hendaklah dikerjakan oleh seseorang yang mempunyai keahlian dalam bidangnya atau profesinya.

Konsep profesionalisme, seperti yang dikembangkan oleh Hall (1968), kata tersebut banyak digunakan peneliti untuk melihat bagaimana para profesional memandang profesinya, yang tercermin dari sikap dan perilaku mereka. Konsep profesionalisme seperti yang dijelaskan Sumardi (2010), bahwa ia memiliki lima prinsip atau muatan pokok, yaitu:

a. Pertama, afiliasi komunitas (community affilition) yaitu menggunakan ikatan profesi sebagai acuan, termasuk di dalamnya organisasi formal atau kelompokkelompok kolega informal sumber ide pertama pekerjaan. Melalui ikatan profesi ini para profesional membangun kesadaran profesi.

b. Kedua, kebutuhan untuk mandiri (autonomy demand) merupakan suatu pandangan bahwa seseorang yang profesional harus mampu membuat keputusan sendiri tanpa tekanan dari pihak lain (pemerintah, klien, mereka yang bukan 
anggota profesi). Setiap adanya campur tangan (intervensi) yang datang dari luar, dianggap sebagai hambatan terhadap kemandirian secara profesional. Banyak yang menginginkan pekerjaan yang memberikan hak-hak istimewa untuk membuat keputusan dan bekerja tanpa diawasi secara ketat. Rasa kemandirian dapat berasal dari kebebasan melakukan apa yang terbaik menurut yang bersangkutan dalam situasi khusus.

c. Ketiga, keyakinan terhadap peraturan sendiri/profesi (belief self regulation) dimaksud bahwa yang paling berwenang dalam menilai pekerjaan profesional adalah rekan sesama profesi, bukan "orang luar" yang tidak mempunyai kompetensi dalam bidang ilmu dan pekerjaan mereka.

d. Keempat, dedikasi pada profesi (dedication) dicerminkan dari dedikasi profesional dengan menggunakan pengetahuan dan kecakapan yang dimiliki. Keteguhan tetap untuk melaksanakan pekerjaan meskipun imbalan ekstrinsik dipandang berkurang. Sikap ini merupakan eskpresi dari pencurahan diri yang total terhadap pekerjaan. Pekerjaan didefinisikan sebagai tujuan. Totalitas ini sudah menjadi komitmen pribadi, sehingga kompensasi utama yang diharapkan dari pekerjaan adalah kepuasan ruhani dan setelah itu baru materi.

e. Kelima, kewajiban sosial (social obligation) merupakan pandangan tentang pentingnya profesi serta manfaat yang diperoleh baik oleh masyarakat maupun profesional karena adanya pekerjaan tersebut.

Lima prinsip tersebut menjelaskan bahwa profesionalisme mengacu pada ketentuan dalam menjalankan profesi yang telah memperoleh pengakuan dari suatu afiliasi, bersikap mandiri dalam mengambil keputusan keprofesian, memahami dan mengikuti unsur regulatif terkait profesinya, memiliki dedikasi, dan menunjukkan tanggungjawab sosial dalam menjalani profesi. Dengan demikian profesionalisme pada dasarnya adalah ciri individu yang menjalankan profesi dengan memenuhi kriteria-kriteria tersebut.

Untuk dapat menjalankan suatu pekerjaan secara profesional atau memiliki profesionalisme, sudah barang tentu diperlukan seperangkat pengetahuan, sikap, dan keterampilan tertentu. Seperti dijelaskan dalam prinsip di atas, bahwa profesionalisme bukan hanya soal pengetahuan, melainkan juga sikap dan keterampilan, maka konsep kompetensi adalah terminologi yang tepat untuk menjelaskan komponen ini.

Jadi dari berbagai pengertian di atas maka yang dimaksud dengan kompetensi profesional guru ialah kemampuan dan kewenangan guru dalam menjalankan profesi keguruannya, artinya guru yang piawai dalam melaksanakan 
profesinya dapat disebut sebagai guru yang kompeten dan profesional.Kompetensi profesional merupakan pekerjaan yang hanya dapat di lakukan oleh seorang yang mempunyai kualifikasi akademik, kompetensi dan sertifikat pendidik sesuai dengan persyaratan untuk setiap jenis dan jenjang pendidikan tertentu.

Kompetensi profesional merupakan kemampuan dasar yang harus dimiliki oleh guru. Ada beberapa pandangan ahli tentang kompetensi profesional guru. Menurut Cooper (1984:15) terbagi kedalam 4 komponen kompetensi dasar, yakni:

a. Mempunyai pengetahuan tentang belajar dan tingkah laku manusia

b. Mempunyai pengetahuan dan menguasai bidang studi yang dibinanya

c. Mempunyai sikap yang tepat tentang diri sendiri, sekolah, teman sejawat dan bidang studi yang dibinanya

d. Mempunyai keterampilan dalam tekhnik mengajar.

Sedangkan menurut Depdibud (1980) ada 10 kemampuan dasar guru, yaitu:

a. Penguasaan bahan pelajaran beserta konsep-konsep dasar keilmuannya

b. Pengelolaan program belajar mengajar

c. Pengelolaan kelas

d. Penggunaan media dan sumber pembelajaran

e. Penguasaan landasan-landasan kependidikan

f. Pengelolaan interaksi belajar mengajar

g. Penilaian prestasi siswa

h. Pengenalan fungsi dan program bimbingan dan penyuluhan

i. Pengenalan dan penyelenggaraan administrasi sekolah serta

j. Pemahaman prinsip-prinsip dan pemanfaatan hasil penelitian pendidikan untuk kepentingan peningkatan mutu pengajaran.

Menurut Permendiknas Nomor 16 Tahun 2007 indikator kompetensi profesional adalah sebagai berikut:

a. Menguasai materi, struktur, konsep, dan pola pikir keilmuan yang mendukung mata pelajaran yang di ampu.

b. Menguasai standar kompetensi dan kompetensi dasar mata pelajaran yang di ampu.

1) Memahami standar kompetensi mata pelajaran yang di ampu.

2) Memahami kompetensi dasar mata pelajaran yang di ampu.

3) Memahami tujuan mata pelajaran yang di ampu. 
c. Mengembangkan materi pembelajaran yang di ampu secara kreatif.

1) Materi pembelajaran yang di ampu sesuai tingkat perkembangan peserta didik.

2) Mengolah materi pelajaran yang diampu secara kreatif sesuai dengan tingkat perkembangan peserta didik

d. Mengembangkan keprofesionalan secara berkelanjutan dengan melakukan tindakan reflektif.

1) Melakukan refleksi terhadap kinerja dalam rangka peningkatan keprofesionalan.

2) Memanfaatkan hasil refleksi dalam rangka peningkatan keprofesionalan.

3) Melakukan penelitian tindakan kelas untuk peningkatan keprofesionalan.

4) Mengikuti kemajuan zaman dengan belajar dari berbagai sumber.

e. Memanfaatkan teknologi informasi dan komunikasi untuk mengembangkan diri.

1) Memanfaatkan teknologi informasi dan komunikasi dalam berkomunikasi

2) Memanfaatkan teknologi informasi dan komunikasi untuk pengembangan diri.

Berdasarkan kriteria yang ditetapkan dalam Permendiknas No. 16 tahun 2007 tersebut, maka kompetensi profesional pada dasarnya merupakan kompetensi keilmuan sesuai dengan bidang tugas guru. Dengan demikian dilihat dari substansinya kompetensi ini akan bervariasi secara keilmuan sesuai dengan bidang studi yang ditekuni selama studi. Ketentuan yang sama juga berlaku sesuai latar belakang studi masing-masing guru, dengan kata lain; seseorang dengan latar belakang akademik bidang Pendidikan Bahasa maka dapat dikatakan berkompeten di bidang Pendidikan Bahasa tapi tidak berkompeten di bidang Pendidikan Matematika. Ilustrasi tersebut menunjukkan bahwa kompetensi profesional ini mengarah pada spesialisasi tugas guru sesuai latar belakang keilmuannya.

Selain dituntut untuk memiliki kompetensi profesional, seorang guru juga harus bisa mengembangkan keprofesionalannya. Hal yang harus dikembangkan terkait dengan pengembangan profesionalannya adalah:

\section{a. Knowledge (pengetahuan)}

Menurut Muhammad Hatta pengetahuan adalah segala sesuatau yang didapat dari membaca dan pengalaman, serta ilmu pengetahuan adalah pengetahuan yang didapat dengan jalan keterangan (analisis). Jadi, pengetahuan adalah sesuatu yang bisa dibaca, dipelajari dan dialami oleh setiap orang.

Nurdin (2004:141) Dalam hal pengembangan profesionalisme guru, menambah 
pengetahuan adalah hal yang mutlak. Selain itu pengetahuan juga harus diasah karna pengetahuan tanpa diasah (diamalkan) tidak aka nada manfaatnya.

b. Ability (kemampuan)

Kemampuan manusia terdiri dari dua unsur yaitu yang bisa dipelajari, misalnya pengetahuan dan keterampilan, serta yang alamiah, mislanya bakat. Seseoran tidak bisa hanya mengandalkan bakatnya saja, karena apabila hanya mengandalkan bakat tanpa mempelajari dan membiasakan kemampuannya, maka ia tidak akan berkembang.

c. Skill (keterampilan)

Keterampilan adalah salah satu kemampuan yang dapat dipelajari. Keterampilan juga merupakan keahlian yang bermanfaat jangka panjang. Seorang guru yang profesional, dituntut untuk memiliki beberapa keterampilan, khusus yang menunjang karirnya sebagai guru. Diantaranya adalah :

1) Guru sebagai pengajar

Guru harus memiliki keterampilan menyampaikan informasi kepada anak didiknya dengan menggunakan Bahasa Indonesia yang benar, bail lisan maupun tulisan.

2) Guru sebagai pemimpin kelas murid.

Guru harus memiliki keterampilan dan memimpin kelompok-kelompok

3) Guru sebagai pembimbing

Guru harus memiliki keterampilan dalam mengarahkan dan mendorong kegiatan belajar siswa.

d. Attitude (sikap diri)

Sikap diri seseorang terbentuk oleh suasana lingkungan sekitarnya. Sikap diri ini juga merupakan kepribadian seseorang. Sikap diri yang sangat diperlukan dalam pengembangan profesionalisme guru diantaranya adalah : disiplin tinggi, percaya diri yang positif, akrab dan ramah, akomodatif, berani berkata benar.

e. Habit (kebisaan diri)

Kebiasaan adalah suatau kegiatan yang terus menerus dilakukan yang tumbuh dari dalam pikiran. Kebiasaan yang harus dimiliki seorang guru adalah kebiasaan yang positif, karena kebiasaan guru secara langsung ataupun tidak langsung juga akan dicontoh oleh siswanya. 


\section{SIMPULAN}

Seperti layaknya profesi lain, untuk menjadi guru profesional diperlukan berbagai kriteria. Kriteria tersebut berupa landasan keprofesionalan profesi guru dan kompetensi guru sebagaimana termuat dalam Undang-undang Guru dan Dosen serta Peraturan Mentri Pendidikan Nasional tentang kompetensi guru. Untuk dapat disebut guru profesional tidak hanya diperlukan kualifikasi pendidikan kesarjanaan bidang pendidikan, melainkan juga pemenuhan terhadap kompetensi profesional, kompetensi pedagogi, kompetensi sosial, dan kompetensi kepribadian. Keempat kompetensi ini merupakan paket utuh yang wajib dimiliki seorang guru sebagaimana diatur dalam peraturan perundangan yang disebutkan sebelumnya. Tidak terpenuhinya kompetensi tersebut akan berpengaruh pada pemenuhan kualitas layanan pendidikan. Berdasarkan uraian di atas, menjadi guru bukanlah pekerjaan yang mudah. Guru bukan hanya menjalankan profesinya ketika dia berada di sekolah, melainkan juga di masyarakat. Ada seperangkat atribut yang melekat pada guru dalam pergaulan di sekolah maupun di masyarakat.

\section{REFERENSI}

Efendi, I., Prawitasari, M., \& Susanto, H. (2021). Implementasi Penilaian Pembelajaran Pada Kurikulum 2013 Mata Pelajaran Sejarah. Prabayaksa: Journal of History Education, 1(1), 21-25.

Susanto, H. (2020). Profesi Keguruan. Banjarmasin: FKIP Universitas Lambung Mangkurat.

Susanto, H., \& Akmal, H. (2018). Efektivitas Penggunaan Aplikasi Pembelajaran Berbasis Mobile Smartphone Sebagai Media Pengenalan Sejarah Lokal Masa Revolusi Fisik Di Kalimantan Selatan Pada Siswa Sekolah Menengah Atas. HISTORIA: Jurnal Program Studi Pendidikan Sejarah, 6(2), 197-206.

Susanto, H., Irmawati, I., Akmal, H., \& Abbas, E. W. (2021). Media Film Dokumenter Masuknya Islam Ke Nusantara dan Pengaruhnya Terhadap Keterampilan Berpikir Kritis Siswa. HISTORIA: Jurnal Program Studi Pendidikan Sejarah, 9(1).

Syaharuddin, S., \& Susanto, H. (2019). Sejarah Pendidikan Indonesia (Era Pra Kolonialisme Nusantara sampai Reformasi). Banjarmasin: FKIP Universitas Lambung Mangkurat. 
Rusman, dkk. (2011). Pembelajaran Berbasis Teknologi Informasi dan Komunikasi Mengembangkan Profesionalisme Guru. Jakarta: Rajawali Pers.

Nurdin, M. (2004). Kiat Menjadi Guru Profesional. Yogyakarta: Ar-Ruzz Media. 